\title{
Effect of Lentil and Buffalo Whey Protein Hydrolysates on Histopathology of Liver and Kidney in Diabetic Rats
}

Gehan Hassan Bisar ${ }^{1}$, Mokhtar Youssef ${ }^{2}$, Khaled El Saadany ${ }^{3}$, Wedad Mohamed El-Kholy ${ }^{1}$ and Ehab Kheadr $^{*}$

${ }^{1}$ Dairy Research Department, Food Technology Research Institute, A.R.C., Cairo, Egypt

${ }^{2}$ Postgraduate Studies and Research Institute, University of Alexandria, Alexandria, Egypt

${ }^{3}$ Department of Dairy Science and Technology, Faculty of Agriculture, Functional Foods and Nutraceuticals Laboratory (FFNL), University of Alexandria, Postal Code 21545 Alexandria, Egypt

\begin{abstract}
This study was undertaken to evaluate the effects of protein hydrolysate prepared from lentil and buffalo whey proteins on body weight and histopathology of alloxan induced diabetic rats. Seventy two male albino rats were randomly divided into non-diabetic, diabetic untreated and diabetic treated with lentil or buffalo whey protein hydrolysates with or without yogurt. Experimental diabetes was induced by a single intraperitoneal (i.p) administration of alloxan (120 mg/kg body weight). Histopathological analyses were conducted on the liver and kidney tissues after 28 day of experiment. While the body weight was significantly decreased in the diabetic control group, there were no significant difference in diabetic treated group $(P<0.05)$. Destruction of the liver architecture of the hepatocytes in the diabetic group showed the signs of steatosis, fibrosis and inflammation in the central vein and blood vessels. In the kidney, intestinal nephrites and mesangial proliferation and formation of cast material were observed. Yoghurt-containing lentil protein hydrolysate contained in yogurt appeared to have remarkable effect to prevent damage in liver and kidney histology caused by diabetes.
\end{abstract}

Keywords: Active peptides; Legumes; Whey proteins; Diabetes; Yoghurt

\section{Introduction}

Beans are nutritional power packed with protein, fiber, B vitamins, iron, potassium, and are low in fat; Studies showed that legumes lower the risk of heart disease and cholesterol due to the presence of fiber in its components. Beans contain a wide range of isoflavones, saponines and phytosterols which reduce cancer.

Beans are a diabetes sufferer's superfood, the balance of complex carbohydrates and protein provides a slow, steady source of glucose instead of the sudden surge that can occur after eating simple carbohydrates $[1,2]$.

Diabetes is an epidemic: It has been estimated that 29.1 million people in the United States have diabetes, and the number is growing nearly 1 in 11 people have diabetes. Eating a variety of legumes, including beans, may be valuable not only in the prevention of diabetes but also in the management of blood sugar levels [1]. Legume fiber was among the fiber types associated with reducing risk for metabolic syndrome, which includes glucose disturbances and increased risk of diabetes [3]. Variety of milk-derived biologically active peptides have been shown to exert both functional and physiological roles in vitro and in vivo, and because of this are of particular interest for food science and nutrition applications. Biological activities associated with such peptides include immunomodulatory, antibacterial, anti-hypertensive and antidiabetic -like properties. Milk proteins are recognized as a primary source of bioactive peptides, which can be encrypted within the amino acid sequence of dairy proteins, requiring proteolysis for release and activation. Fermentation of milk proteins using the proteolytic systems of lactic acid bacteria is an attractive approach for generation of functional foods enriched in bioactive peptides given the low cost and positive nutritional image associated with fermented milk drinks and yoghurt.

\section{Experimental Procedure}

\section{Protein hydrolysis}

Lentil and buffalo whey protein hydrolysate were prepared according to previous method described by Ramkrashan [4]. Briefly, protein solution $(2 \% \mathrm{w} / \mathrm{w}$ on protein basis) was made by dispersion the legume protein isolate buffalo whey protein in $100 \mathrm{ml}$ of MCIVANS buffer. Two enzymes were used in hydrolysis process starting with alcalse (Novozyme, and Biotechnology Company in Bagsværd, Kobenhavn, Denmark) for $6 \mathrm{~h}$ at $\mathrm{pH} 8$ and $50^{\circ} \mathrm{C}$, followed by pepsin (LOBA CHEMIE PVT.LTD) for $18 \mathrm{~h}$ at $\mathrm{pH} 3$ and $37^{\circ} \mathrm{C}$. The hydrolysates were freeze dried and kept at $-20^{\circ} \mathrm{C}$.

\section{Antidiabetic in vitro assessment}

Freeze dried protein hydrolysates were subjected to antidiabetic activity assessment according to the methods described previously [5] On which upon that test the antidiabetic activity shown from buffalo whey protein and lentil hydrolysates were 82.4 and $72.5 \%$, respectively.

\section{Yogurt processing}

Full-fat cow's milk was purchased from local market, standardized by $65 \mathrm{~g}$ skim milk powder and a $100 \mathrm{ml}$ of protein hydrolysate in case

*Corresponding author: Kheadr E, Department of Dairy Science and Technology, Faculty of Agriculture, Functional Foods and Nutraceuticals Laboratory (FFNL) University of Alexandria, Postal code 21545 Alexandria, Egypt, Tel: +203-5921960; +203-5921862; +203-5915427; Fax: +203-5922780; E-mail: ehabkheadr@hotmail.com

Received November 01, 2017; Accepted November 25, 2017; Published December 04, 2017

Citation: Bisar GH, Youssef M, Saadany KE, El-Kholy W, Kheadr E (2017) Effect of Lentil and Buffalo Whey Protein Hydrolysates on Histopathology of Liver and Kidney in Diabetic Rats. J Cytol Histol 8: 489. doi: 10.4172/2157-7099.1000489

Copyright: @ 2017 Bisar GH, et al. This is an open-access article distributed under the terms of the Creative Commons Attribution License, which permits unrestricted use, distribution, and reproduction in any medium, provided the original author and source are credited. 
of lentil protein hydrolysate and a $200 \mathrm{ml}$ hydrolysate in case of buffalo protein hydrolysate. Milk was then pasteurized at $63^{\circ} \mathrm{C}$ for $30 \mathrm{~min}$, cooled down to $42^{\circ} \mathrm{C}$, inoculated with $2 \%(\mathrm{w} / \mathrm{w})$ of yogurt starter culture composed of Streptococcus thermophilus and Lactobacillus bulgaricus. Milk was incubated at $42^{\circ} \mathrm{C}$ for $2 \mathrm{~h}$. Yoghurt was then refrigerated at 5 $\pm 1^{\circ} \mathrm{C}$ till used.

\section{Animals}

After acclimatization period of 10 days, 72 albino male rats (weight) were assigned randomly into 6 groups (12 rats/group). Animals were housed in cages (6/cage) under proper environmental conditions and kept on commercial diet (bady namy el fagr 23\%) according to Demerdash et al. [6]. Rats were fed pellets consisted of 30\% barsium (Trifollium allexandrinum) hay, 25\% yellow corn, 26\% wheat bran, $14 \%$ soy bean meal, $3 \%$ molasses, $1 \%$ calcium dichloride, $0.4 \%$ sodium chloride, $0.3 \%$ mixture of minerals and vitamins $(0.01 \mathrm{~g} / \mathrm{kg}$ diet of vitamin E), 0.1 methionine. The chemical analysis of the pellets [7] showed that they contained $17.5 \%$ crude protein, $14 \%$ crude fiber, $2.7 \%$ crude fat and $2200 \mathrm{kcal} / \mathrm{kg}$ diet, tap water provided ad lipitum and kept for 2 weeks for acclimatization and maintained at $25 \pm 1^{\circ} \mathrm{C}$ with 12 dark and light cycle [8].

Diabetes was induced in rate by a single intraperitoneal administration of alloxan (obtained from alpha company from India) $(120 \mathrm{mg} / \mathrm{kg}$ body weight) as described previously. After stabilization of diabetes for 2 week, rats were subjected to an experimental period of 28 days [9].

\section{Experimental Design}

Animals were divided into 6 major groups as following:

Group 1 (C): 12 non-diabetic rats kept as negative control,

Group 2 (CD): 12 diabetic rats kept as positive diabetic control,

Group 3 (DB): 12 diabetic rats received an intra-gastric dose of buffalo protein hydrolysate $(1000 \mathrm{mg} / \mathrm{kg} /$ week/day),

Group 4 (DBY): 12 diabetic rats received an intra-gastric dose of buffalo protein hydrolysate contained in yogurt $(1000 \mathrm{mg} / \mathrm{kg} /$ week/ day),

Group 5 (DL): 12 diabetic rats received an intra-gastric dose of lentil protein hydrolysate $(1000 \mathrm{mg} / \mathrm{kg} / \mathrm{week} /$ day $)$,

Group 6 (DLY): 12 diabetic received an intra-gastric dose of lentil protein hydrolysate contained in yogurt $(1000 \mathrm{mg} / \mathrm{kg} /$ week/day).

\section{Histopathological Study}

Histopathological examination was carried out according to Drury et al. [10] the kidney and liver was dissected and the tissue sample were fixed in 10\% formalin solution for 14-18 hours and then dehydrated through ascending grades of ethyl alcohol until they reached the absolute alcohol (1 hour). They were then transferred to xylol. Organs were placed in a mixture of melted wax and xylol (1:1) for about 10 minutes and transferred to paraffin wax $56^{\circ} \mathrm{C}$.

For sectioning, the paraffin blocks were mounted in a microtome where successive sections adhere to form a straight ribbon. The slide was hold high over a Bunsen burner flame till the sections flatten out and firmly adhere to the slide. Slides were immersed in xylol for three minutes to dissolve the paraffin and then transferred to absolute alcohol for one minute to remove the xylitol and then sections were dehydrated by passing them down $96 \%, 90 \%, 80 \%$, 70\%and 50\%alchol for one minute in each. The double or counter staining method was used, Slides were dipped in haematoxylin for ten minutes and then washed with distilled water. Then slides were transferred to $70 \%$ then rinsed in alkaline water. The excess stain was removed with distilled water,sections were again dehydrated by passing by in a series of 70,80 , 90 and $96 \%$ alcohol for 2 minutes, then twice in $100 \%$ alcohol. Sections were cleared by passing twice in xylol for two minutes. Finally, sections were embedded in Canada balsam, covered with a thin cover glass, and then dried in an oven $\left(40^{\circ} \mathrm{C}\right)$ to harden the balsam. Sections were examined for histopathological changes.

\section{Statistical Analysis}

Experimental data were statistically analyzed with one-way ANOVA and 11 multiple range tests and expressed as mean values \pm SE. Effects with a probability of $P<0.05$ were considered significant. Statistical analyses were performed using SPSS for Windows (Standard Version 17 SPSS Inc. Chicago, Illinois).

\section{Results}

Table 1 demonstrates changes in body weight of control and diabetic groups. The initial body weight did not significantly among groups, while net weight gain (calculated by subtracting initial weight from final weight) differed significantly $(P<0.05)$ depending on applied treatment. Net weight gain of $47.6 \mathrm{~g}$ was calculated for non-diabetic group C. Group subjected to treatment DC exhibited negatively weight gain (-17 g) compared to group C. the administration of either protein hydrolysates alone or in combination with yoghurt improved weight gain by diabetic groups. Net gains of $46.6,36.2,21.4$ and $44.6 \mathrm{~g}$ were reported for groups DB, DBY, DL and DLY, respectively.

Table 1 also shows weight of different organs (liver, kidney, heart, lung, brain and spleen) of control and diabetic animals. Among animal groups, animals subjected to group CD had the highest $(P<0.05)$ weight of different organs. However, groups subjected to treatments DB, DBY, DL and DLY exhibited values lower than those obtained for CD group but quite similar to those determined for control group.

Histopathological evaluation of the normal liver tissue of the non-diabetic rats demonstrated the normal hepatic structure in which lobule is made up of radiating plates, strands of cells forming

\begin{tabular}{|l|c|c|c|c|c|c|}
\hline \multirow{2}{*}{ Weight (g) } & \multicolumn{7}{|c|}{ Experimental groups } \\
\cline { 2 - 7 } & C & CD & DB & DBY & DL & DLY \\
\hline Initial Body Weight & $194.40^{\mathrm{a}}$ & $193.20^{\mathrm{a}}$ & $194.40^{\mathrm{a}}$ & $194.80^{\mathrm{a}}$ & $194.60^{\mathrm{a}}$ & $195.40^{\mathrm{a}}$ \\
\hline Final Body Weight & $242.00^{\mathrm{a}}$ & $176.00^{\mathrm{b}}$ & $241.00^{\mathrm{a}}$ & $231.00^{\mathrm{a}}$ & $236.00^{\mathrm{a}}$ & $238.00^{\mathrm{a}}$ \\
\hline Liver & $6.64^{\mathrm{b}}$ & $8.35^{\mathrm{a}}$ & $6.84^{\mathrm{b}}$ & $6.21^{\mathrm{b}}$ & $6.48^{\mathrm{b}}$ & $6.34^{\mathrm{b}}$ \\
\hline Kidney & $1.92^{\mathrm{ab}}$ & $2.27^{\mathrm{a}}$ & $1.88^{\mathrm{b}}$ & $1.78^{\mathrm{b}}$ & $1.58^{\mathrm{b}}$ & $1.76^{\mathrm{b}}$ \\
\hline Heart & $0.70^{\mathrm{b}}$ & $0.89^{\mathrm{a}}$ & $0.73^{\mathrm{b}}$ & $0.67^{\mathrm{b}}$ & $0.64^{\mathrm{b}}$ & $0.50^{\mathrm{c}}$ \\
\hline Lung & $1.70^{\mathrm{b}}$ & $2.16^{\mathrm{a}}$ & $1.71^{\mathrm{b}}$ & $1.60^{\mathrm{b}}$ & $1.63^{\mathrm{b}}$ & $1.64^{\mathrm{b}}$ \\
\hline Brain & $1.42^{\mathrm{ab}}$ & $1.64^{\mathrm{a}}$ & $1.31^{\mathrm{b}}$ & $1.43^{\mathrm{ab}}$ & $1.33^{\mathrm{b}}$ & $1.38^{\mathrm{ab}}$ \\
\hline Testes & $6.08^{\mathrm{b}}$ & $5.32^{\mathrm{c}}$ & $5.76^{\mathrm{bc}}$ & $5.81^{\mathrm{bc}}$ & $5.86^{\mathrm{bc}}$ & $6.70^{\mathrm{a}}$ \\
\hline Spleen & $0.60^{\mathrm{c}}$ & $0.73^{\mathrm{a}}$ & $0.62^{\mathrm{bc}}$ & $0.61^{\mathrm{bc}}$ & $0.63^{\mathrm{bc}}$ & $0.66^{\mathrm{b}}$ \\
\hline Pancreas & $0.44^{\mathrm{a}}$ & $0.30^{\mathrm{c}}$ & $0.41^{\mathrm{ab}}$ & $0.38^{\mathrm{b}}$ & $0.43^{\mathrm{a}}$ & $0.43^{\mathrm{a}}$ \\
\hline
\end{tabular}

Means in the same raw within each item having different superscripted are significantly different $(p<0.05)$.

C: Control group non diabetic rats, CD: Diabetic rats administrated no treatment DB: Diabetic rats administrated buffalo whey protein hydrolysate, DBY: Diabetic rats administrated yogurt contain buffalo protein hydrolysate, DL: Diabetic rats administrated lentil protein hydrolysate and DLY: Diabetic rats administrated yogurt contain lentil protein hydrolysate.

Table 1: The effect of buffalo whey and lentil protein hydrolysate on body and organs weight of control and diabetic rats. 
Citation: Bisar GH, Youssef M, Saadany KE, El-Kholy W, Kheadr E (2017) Effect of Lentil and Buffalo Whey Protein Hydrolysates on Histopathology of Liver and Kidney in Diabetic Rats. J Cytol Histol 8: 489. doi: 10.4172/2157-7099.1000489

a network around a central vein (Figure 1a). Liver sections of diabetic induced-rats revealed hepatocellular injury confirmed by the loss of normal architecture of the liver, inflammation, dilation in central vein, moderate fibrosis and leucocytic infiltration around central vein (Figure 1b). These structural characteristics were less pronounced in diabetic animals administrated either protein hydrolysates alone or combined to yoghurt (Figure 1c-1f). Histopathological evaluation of the kidney sections of normal (Figure 2), induced diabetic rats and treated, Figure 3 demonstrates histological slides were assessed for scoring of liver disease by grading modified HAI, fibrosis and steatosis. Figure 4 show histological slides were assessed for scoring of kidney disease regarding CAST material deposition in tubules, mesangial proliferation and intestinal nephrites.

\section{Discussion}

Studies on diabetes mellitus showed that the occurrence of oxidative stress rises because of increasing the level of free radicals and diminish
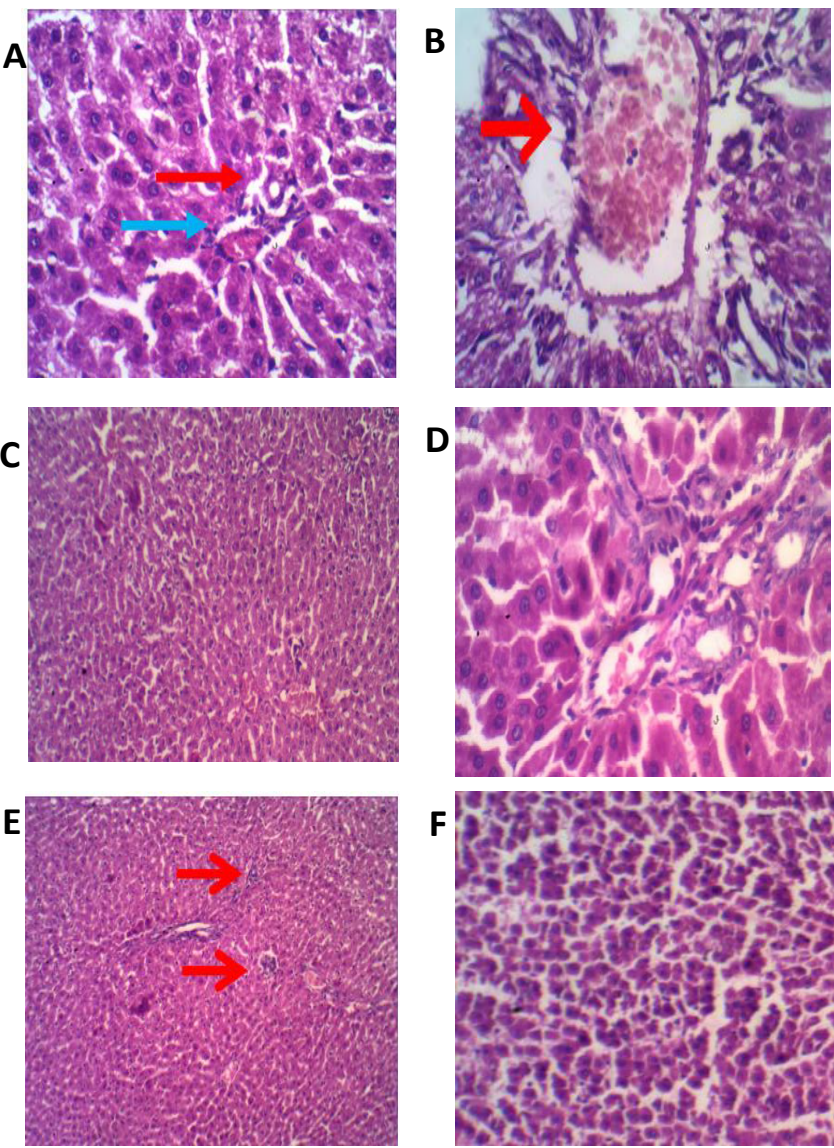

Figure 1: Photomicrographs of histological sections of liver tissue of control and treated rats. (A) Non-diabetic section of liver showing normal histological structure of hepatocytes H\&E 40X. (B) Liver of diabetic rat showing loss of the normal architecture with the distended portal vein, fibrosis, leucocytic inflammation, H\&E 40X. (C) Diabetic liver treated with buffalo protein hydrolysate shows portal inflammation Modified $\mathrm{HAI}(1,0,1,2)=4 / 18$ moderate necroinflamatory activity and hemorrhage in between hepatocites H\&E, 10X. (D) Diabetic rats treated with buffalo protein hydrolysate contained in yogurt show Portal tract showing mild fibrous expansion without sep Mild focal inflammation formed of Lymphocutes. Mild venous congestion (10x). (E) Diabetic rats treated with lentil protein hydrolysate show Tiny residual foci inflammation $(0,0,1,1)=2 / 18$ minimal necroinflamatory activity. (F) Diabetic rats treated with lentil protein hydrolysate contined in yogurt show near normal hepatocytes, Portal tract and focal inflammation. Modified $\mathrm{HAI}(0,0,0,1) \mathrm{H} \& \mathrm{E} X 40$.
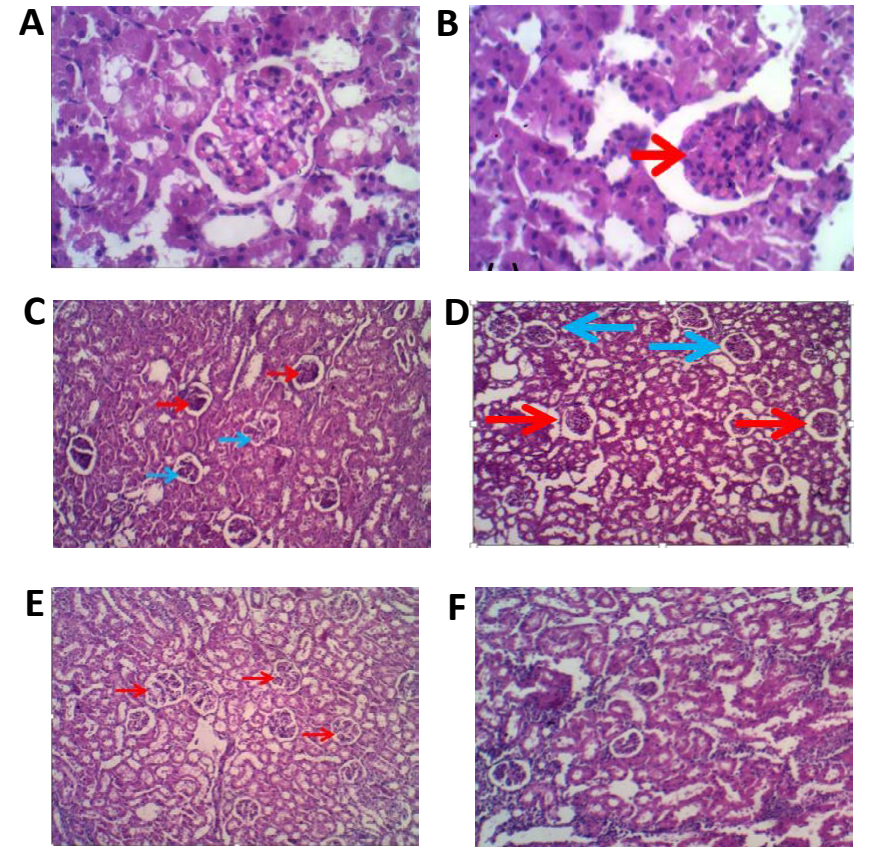

Figure 2: Photomicrographs of histological section of kidney tissue of control and treated rats, (A) Nondiabetic section of kidney showing normal structure with no pathological changes appearance of kidney, normal glomeruli, and tubules, glomerulus, proximal tubule, distal convoluted tubular, Macula Densa cell, H\&E 40X. (B) Diabetic section of kidney glomerulus showing obliterated capillaries and mesangial proliferation, interstitial inflammation formed of lymphocytes, and tubules showing cast deposition. (H\&E, 40X). (C) kidney section from diabetic rats treated with buffalo protein hydrolysate showing that some glomeruli with obliterated capilliries by mesangial proliferation while others with patent capillaries (samples stained with H\&E 10x) focal mild interstaial nephrites inflammation. (D) Kidney section from diabetic rats treated with buffalo protein hydrolysate contained in yogurt showing that some globurilli with obliterated capillaries by mesangial proliferation while others shows patent capillaries stained by H\&E at $10 x$. There is no inflammation detected $(E)$ kidney section from diabetic rats treated with lentil protein hydrolysate showing that Most all glomeruli showed patent capillaries and characteristic lobulation of the glomeruli (H\&E 10X). No cast in the tubules (F) kidney section from diabetic rats treated with lentil protein hydrolysate contained in yogurt show normal glomerulus, normal basement membrane, and capillaries, without any inflammatory cells, Free tubules no cast shown H\&E X10.

cells antioxidant capabilities that subsequently can cause oxidative stress and tissue damage in diabetic patients [11-13]. These activities of exogenous and endogenous antioxidant, contributes a key role in the defense against free radicals [14]. Alloxan has been extensively used to induce diabetes mellitus in animals where it is well known for its selective pancreatic islet $\beta$-cell cytotoxicity, also interferes with cellular metabolic oxidative mechanisms [15]. Diabetic rats exhibit high oxidative stress due to chronic hyperglycemia that result in depletion of the antioxidant defense system and promotes the generation of free radicals [16]. Alloxan induced diabetes is characterized by polydypsia, polyuria, weight loss, decreased physical activities and hyperglycemia [17]. Histopathological examinations demonstrated mild to moderate inflammation of the hepatocytes, ROS and lipid peroxidation cause direct damage to hepatocytes by disrupting membranes, protein [18]. In the alloxan induced diabetic animals, were shown to lower levels of activities of endogenous antioxidant enzymes such as SOD and CAT. Subsequently, these reductions can cause tissue degradations [13]. Liver and kidney are important organs of storage, detoxification, metabolism, and excretion of many metabolites, so they are 


\section{STEATOSIS}

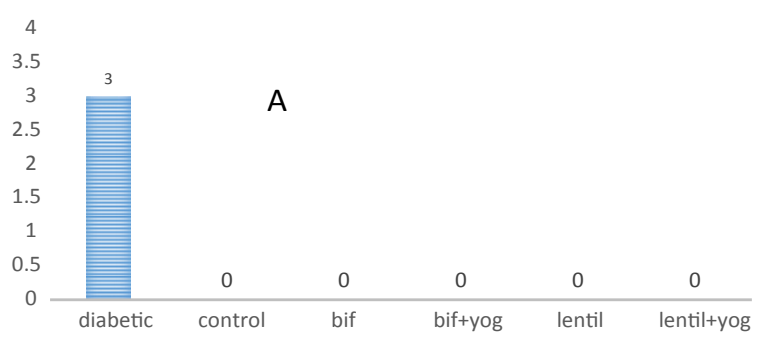

C

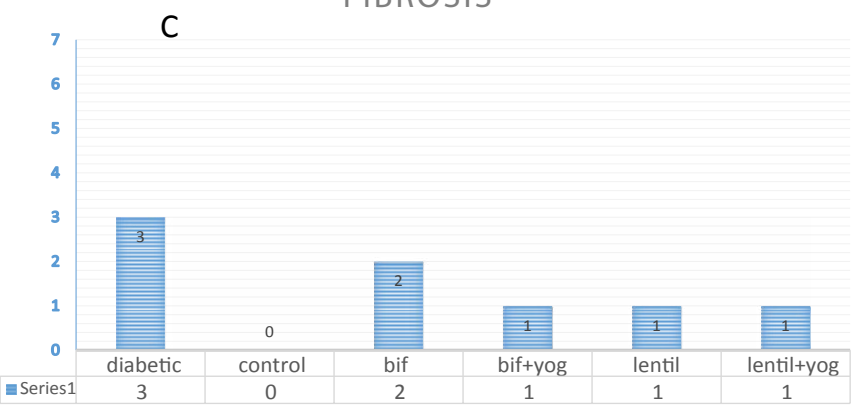

MODIFIED HAI

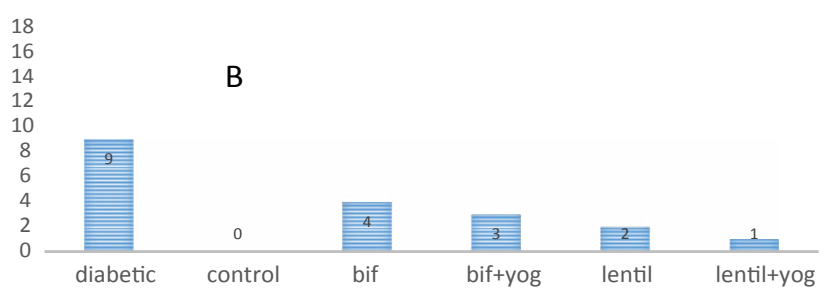

Figure 3: Histological slides were assessed for scoring of liver disease by grading modified HAI, fibrosis and steatosis modified HAI scoring system: this system scores necro-inflammatory activity from: 0 to 18 and the scoring The fibrosis scores are defined on a scale from 0 to 6 . Steatosis percent, assigned as described in the literature on the basis of percentages. Less than 5 no steatosis, mild from $5-33$, from $33-66 \%$ moderate and marked steatosis more that $66 \%$.

\section{Kidney}

Scoring

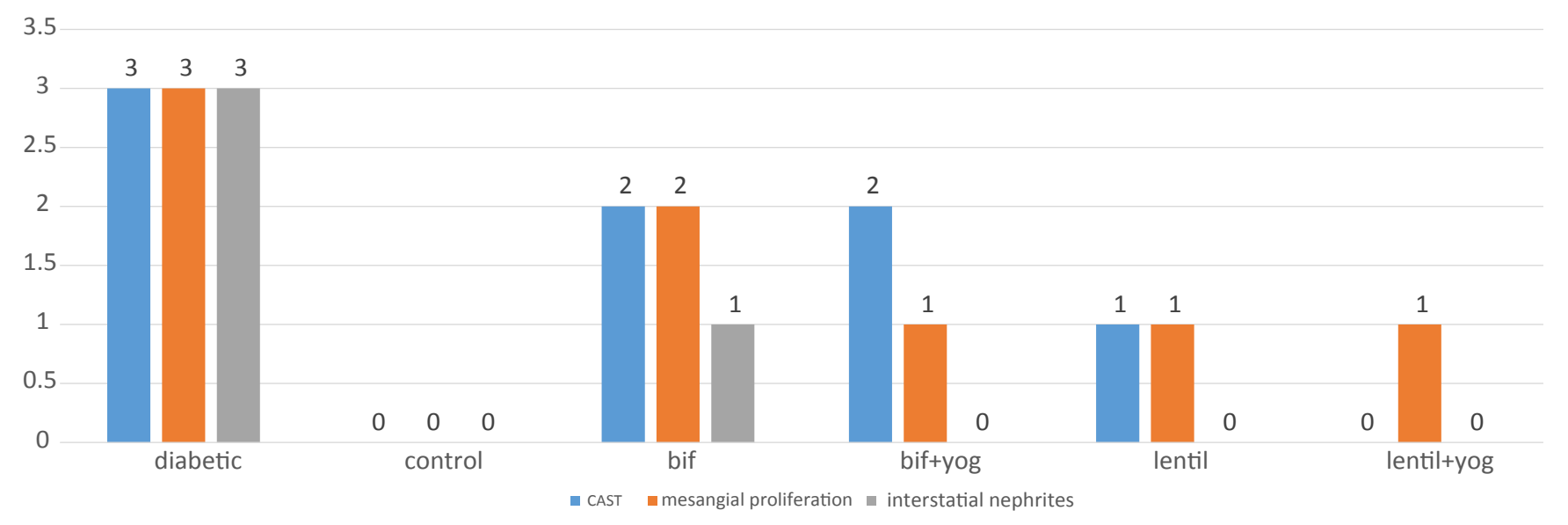

Figure 4: Histological slides were assessed for scoring of kidney disease regarding CAST material deposition in tubules, mesangial proliferation and intestinal nephrites, the score is out of 3 then $3(+++)$ that indicates sever, $2(++)$ moderate and $1(+)$ mild case.

particularly vulnerable to oxidative damage [19]. Liver is important organ that its main function is maintaining and control blood glucose with glycogenesis and glycogenolysis. Hepatocyte damage and lipid peroxidation products induce an inflammatory response. The mechanism of liver and kidney destruction because of the oxidative stress involves the secretion of cytokines, mainly tumor necrosis factor [20]. These alterations might cause an abnormal production of cytokines and growth factors. Subsequently, they facilitate the synthesis of extracellular matrix proteins and the depositions in the glomerular level that finally lead to mesangial expansion, glomerular shrinkage, and glomerular basement thickening. High glucose levels directly increases hydrogen peroxide production in the murine mesangial cells [21], and lipid peroxidation of the glomerulus [22,23]. Therefore, oxidative stress can be the common pathogenic factor for diabetic nephropathy similar to other complications [24]. Diabetic nephropathy is a widespread complication of diabetes mellitus. Consequently, some positive attributes of lentil protein hydrolysate in this study may be the ability to lower the oxidative stress. High level of antioxidant in lentil protein hydrolysate could boost to quenching of some free radicals inside cells, 
Citation: Bisar GH, Youssef M, Saadany KE, El-Kholy W, Kheadr E (2017) Effect of Lentil and Buffalo Whey Protein Hydrolysates on Histopathology of Liver and Kidney in Diabetic Rats. J Cytol Histol 8: 489. doi: 10.4172/2157-7099.1000489

Page 5 of 6

as well as have the capability to protect kidney and liver tissue from oxidative stress damage

\section{Histological Examination of Liver and Kidney Tissues}

The light micrographs of liver tissues demonstrated normal architecture of hepatic cells, central vein and normal blood sinusoids in the control group of liver tissue and a normal glomurilies patent capillaries and characteristic lobulation, also free tubules no cast material, no inflammation detected in the control group of the kidney tissue (Figure 1A). In alloxan diabetic group of rats, hepatocytes damage was manifested by marked pyknotic nuclei, portal tract inflammation, and fibrous expansion in the portal tract and congestion in the portal vein (Figure 1B-1F). Also steatosis was shown in liver tissues. These degenerative changes in the histology of the liver tissue brought about by alloxan administered are similar to the observation [25].

In kidney tissues, mesangial cell proliferation causing obliteration in the capillaries cast deposition inside the tubules and a lymphocytic interstitial inflammation were the common structural characteristics diabetic kidneys (Figure 2B-2F). These structural futures were more evident in rats subjected to treatment DC but less pronounced in diabetic rats administrated either buffalo whey or lentil protein hydrolysates either alone or in combination with yoghurt. Also abnormal localization and infiltration of hepatocytic nuclei were appreciated. However, livers of rats treated with buffalo milk protein hydrolysate and lentil protein hydrolysate and their combination with yogurt treated groups (Figure $1 \mathrm{C}-1 \mathrm{~F}$ ) revealed that most of the histological alteration induced in alloxan diabetic group were markedly reduced; histological examination of rat liver manifested that the changes observed after alloxan treatment were attenuated to a moderate alterations while the treated rats liver manifested changes observed in their tissues were attenuated to mild alterations these results in agreement with Aniya et al. [26] who reported that the liver cells from the rats that were pretreated with the extract of monascus anka before the D-galactosamine treatment shown only a slight necrosis.

\section{Conclusion}

The histopathological observations reported in the present study displayed the congestion of portal triad with mild inflammation and remarkable fibrosis near the central vein in the liver, tubular inflammation and glomeruli shrinkage in the kidney. These reactions are provoked by the increased production of highly reactive oxygen species, which are normally detoxified by endogenous antioxidant enzyme in the excessive presentation. The depletion of exogenous antioxidant store can permit the reactive intermediate to react with and destroy the hepatic and renal cells. Such pathological changes can be observed in diabetic rats. Apparently, treatments with lentil and buffalo whey protein hydrolysates might increase the activity of antioxidant enzymes, which have the ability to ameliorate oxidative stress and protect the hepatic and renal tissues in diabetic rats.

\section{Acknowledgement}

The authors would like to thank science and technology development fund (STDF), Egyptian Ministry of Scientific Research, for establishment and supporting functional foods and nutraceuticals laboratory (FFNL) at Alexandria University (Project ID 4876).

\section{References}

1. Venn BJ, Mann JI (2004) Cereal grains, legumes and diabetes. Eur J Clin Nut 58: $1443-1461$

2. Lathwood P, Pollet $P$ (1988) Effects of slow release carbohydrates in the form of bean flakes on the evolution of hunger and satiety in man. Appetite 10:1-11.
3. Hosseinpour-Niazi S, Mirmiran P, Sohrab G, Hosseini-Esfahani F, Azizi F (2011) Inverse association between fruit, legume, and cereal fiber and the risk of metabolic syndrome: Tehran lipid and glucose study. Diabetes Res Clin Prac 94: 276-283.

4. Kaseraa AB, Singha S, KomarlaL, Prasad N, Aroraa N (2015) Enzymatic hydrolysis: A method in alleviating legume allergenicity. Food and ChemicalToxicology 76: 54-60.

5. Manikandan R, Anand VA, Muthumani GD (2013) Phytochemical and in vitro anti-diabetic activity of methanolic extract of Psidium guajava leaves. Int J Curr Microbiol App Sci 2: 15-19.

6. Demerdash EL, Youssef FM, Abou El-Naga NI (2005) Biochemical study on the hypoglycemic effects of onion and garlic in alloxan-induced diabetivc rats. Food and Chemical Toxicology 43: 57-63.

7. AOAC (1990) Official methods of analysis of association of official analytical agricultural chemists, (13thedn), Washington, DC.

8. Childs AC, Phaneuf SL, Dirks AJ, Philips T, Leeuwenburgh C (2002) Doxorubicin treatment in vivo causes cytochrome $C$ release and cardiomyocyte apoptosis, as well as increased mitochondrisl efficiency, superoxide dismutase activity, and Bcl-2: Bax ratio. Cancer Res 62: 4592-4598.

9. Mansour HA, NewairyAS, Yousef MI, Sheweita SA (2002) Biochemical study on the effect of some Egyptians herbs in alloxan-induced diabetic rats. Toxicology 170: $221-228$.

10. Drury RA, Wallington EA, Carleton S (1980) Histological Techniques (5thedn) Oxford University Press, London, New York, Toronto 241-242.

11. Duncan DB (1955) Multiple range and multiple F tests. Biometrics 11: 1-42.

12. Descorbeth M, Anand-Srivastava MB (2010) Role of oxidative stress in highglucose- and diabetes-induced increased expression of $\mathrm{Gq} / 11$ alpha proteins and associated signaling in vascular smooth muscle cells. Free Radic Biol Med 49: 1395-1405

13. Chang YC, Chuang LM (2010) The role of oxidative stress in the pathogenesis of type 2 diabetes: from molecular mechanism to clinical implication. Am J Transl Res 2: 316-331.

14. Chtourou Y, Fetoui H, Sefi M, Trabelsi K, Barkallah M, et al. (2010) Silymarin, a natural antioxidant, protects cerebral cortex against manganese-induced neurotoxicity in adult rats. Biometals 23: 985-996.

15. Papaccio G, Pisanti FA, Latronico MV, Ammendola E, Galdieri M (2000) Multiple low-dose and single high-dose treatments with streptozotocin do not generate nitric oxide. J Cell Biochem 77: 82-91.

16. Maritim AC, Sanders RA, Watkins JB 3rd (2003) Diabetes, oxidative stress, and antioxidants: a review. J Biochem Mol Toxicol 17: 24-38.

17. Shenoy AG, Ramesh KG (2002) Improvement of insulin sensitivity by perindopril in spontaneously hypertensive and streptozotocin-diabetic rats. Ind J Pharmacol 34: 156-164.

18. Peterson DT, Greene WC, Reaven GM (1971) Effect of experimental diabetes mellitus on kidney ribosomal protein synthesis. Diabetes 20: 649-654.

19. Brzoska MM, Moniuszko-Jakoniuk J, PiÅ,at-Marcinkiewicz B, Sawicki B (2003) Liver and kidney function and histology in rats exposed to cadmium and ethanol. Alcohol Alcohol 38: 2-10.

20. Sugano M, Yamato H, Hayashi T, Ochiai H, Kakuchi J, et al. (2006) High-fat diet in low-dose-streptozotocin-treated heminephrectomized rats induces all features of human type 2 diabetic nephropathy: a new rat model of diabetic nephropathy. Nutr Metab Cardiovasc Dis 16: 477-484.

21. Ruiz-Muñoz LM, Vidal-Vanaclocha F, Lampreabe I (1997) Enalaprilat inhibits hydrogen peroxide production by murine mesangial cells exposed to high glucose concentrations. Nephrol Dial Transplant 12: 456-464.

22. Ha H, Kim KH (1999) Pathogenesis of diabetic nephropathy: the role of oxidative stress and protein kinase C. Diabetes Res Clin Pract 45: 147-151.

23. Ha H, Yoon SJ, Kim KH (1994) High glucose can induce lipid peroxidation in the isolated rat glomeruli. Kidney Int 46: 1620-1626.

24. Schleicher E, Kolm V, Ceol M, Nerlich A (1996) Structural and functiona changes in diabetic glomerulopathy. Kidney Blood Press Res 19: 305-315. 
Citation: Bisar GH, Youssef M, Saadany KE, El-Kholy W, Kheadr E (2017) Effect of Lentil and Buffalo Whey Protein Hydrolysates on Histopathology of Liver and Kidney in Diabetic Rats. J Cytol Histol 8: 489. doi: 10.4172/2157-7099.1000489

Page 6 of 6

25. Abdultawab HS, Ayuob NN (2013) Can garlic oil ameliorate diabetes-induced oxidative stress in a rat liver model? A correlated histological and biochemical study, Food and Chemical Toxicology 59: 650-656.
26. Aniya Y, Yokomakura T, Yonamine M, Shimada K, Nagamine T (1999) Screening of antioxidant action of various molds and protection of Monascus anka against experimentally induced liver injuries of rats. Gen Pharmacol 32 225-231. 